\title{
EVALUATION OF SAFETY AND EFFICACY OF MYOMECTOMY DURING CESAREAN SECTION- CASE CONTROL STUDY
}

\author{
By

\section{Ayman Gamil Morzak, Mohammad Salah El-Deen Hassanin and Taher Mohammad Mostafa}

Obstetrics and Gynecology Department, Faculty of Medicine, Al-Azhar University, Egypt

*Corresponding author: Ayman Gamil Morzak,

Mobile: 01095556090, E-mail: aymangamil75@yahoo.com

\begin{abstract}
Background: Uterine fibroid (Leiomyomata) is the most common benign tumor in women. It may be solitary, multiple or diffuse, there is a genetic predisposition to the development of leiomyomata.

Objective: To evaluate the safety and efficacy of myomectomy during cesarean section.

Patients and methods: A case control study was conducted in Obstetrics and Gynecology Department, Faculty of Medicine, Al-Azhar University during the period from 1st of December 2018 to 30th November 2019. It included 80 patients who underwent to cesarean section. The patients were divided into two equal groups: Group A had been undergone to myomectomy during cesarean section while control group B were only cesarean section without any other intervention.

Results: Pre/postoperative hemoglobin was slightly lower in group A compared to group B without statistically significant difference and no significant change in hemoglobin value from preoperative to postoperative. Mean blood loss was slightly higher in group A compared to group B without significant difference. Meanwhile, blood transfusion and postoperative fever were more frequent in group A but without significant difference. BMI, myomectomy with CS, and fibroid size $3-6 \&>6 \mathrm{~cm}$ were found to significant risk factors for hemorrhage.
\end{abstract}

Conclusion: Myomectomy during caesarean section was safe and cost effective as it avoid possible fibroid removal at later age.

Keywords: Myomectomy, Cesarean Section, Cesarean myomectomy.

\section{INTRODUCTION}

Uterine fibroids (Leiomyomata) more common in black women than in white women with a ratio of between 3 and 9:1. Other risk factors for developing fibroids include overweight and nulliparity (Zimmermann et al., 2012).

The precise etiopathology of uterine fibroids is still unclear, although, as they are characterized by a greater concentration of estrogen and progesterone receptors that adjacent myometrium, the key role of ovarian hormones is widely accepted (Nair and Al-Hendy, 2011). Uterine leiomyoma occurs during pregnancy with a reported prevalence of up to $10 \%$ (Lee et al., 2010). Ultrasound studies of fibroids have shown that the majority $(60-78 \%)$ do not significantly change in volume during pregnancy (Allameh and Allameh, 2019). 
Some studies have described a good outcome of myomectomy was performed in the first and second trimester of pregnancy particularly if the myoma did not enter into the uterine cavity (Zhang and Hua, 2014). Myomectomy during C.S is still controversial, even so a welltolerated and feasible procedure (Tpoçu et al., 2015). Routine myomectomy has to be executed only if unavoidable to facilitate, safe delivery of the fetus or closure of uterine scare (Sparić et al., 2015). The advantages of cesarean myomectomy is to avoid the need for interval myomectomy and to decrease the risk of complication of associated with fibroids in successive pregnancies, also it increases the possibilities of vaginal deliveries in subsequent deliveries (Vitale et al., 2015).

We aimed in this study to evaluate the safety and efficacy of myomectomy during cesarean section.

\section{PATIENTS AND METHODS}

A case control study was conducted in Obstetrics and Gynecology Department, Faculty of Medicine, Al-Azhar University during the period from $1^{\text {st }}$ of December 2018 to $1^{\text {st }}$ of January 2020. It included 80 patients who underwent to cesarean section.

The patients were divided into two equal groups:

- Group A had been undergone to myomectomy during caesarean section.

- Group B only caesarean delivery without any other intervention.

\section{Inclusion criteria:}

1. Documented fibroid during the index pregnancy by antenatal ultrasound or at surgery.
2. Delivery by cesarean section.

3. No evidence of antenatal bleeding.

4. No other procedure at cesarean apart from myomectomy.

5. No pre-existing coagulopathy.

All pregnant women were subjected to complete history, general and abdominal examination.

\section{Surgical technique:}

\section{Preoperative:}

- Routine preoperative investigation (e.g., CBC, coagulation profile, Kidney function test and live function test).

- Adequate blood and blood products were arranged.

- Prophylactic antibiotics were administered to all the patients.

\section{Operative:}

- Myomectomy was performed in the conventional fashion using an incision over the myoma, enucleating it, and obliterating the dead space in two to three layers using interrupted 1-0 Vicryl sutures (Ethicon).

- Anterior lower segment myomas encroaching on the proposed incision line were excised prior to delivery of the baby while the others were removed after the baby had been delivered. The Caesarean incision was closed in 2 layers with 1-0 Vicryl sutures.

- High dose oxytocin was used intraoperatively and postoperatively, and some patients required additional uterotonic agents. 
- Blood loss was estimated from suction aspiration, and from weighing mops, swabs and drapes used during surgery.

The aim and nature of the study were explained for each patient before inclusion and informed consents were obtained from patients.

\section{Statistical analysis:}

The two groups had been compared in terms of intraoperative blood loss, requirement of blood transfusion, postoperative HB level and median time for hospital stay. Statistical analysis was done using IBM@ $\odot$ SPSS $\odot$ Statistics version 22 (IBMC) Corp., Armonk, NY, USA). Numerical data were expressed as mean and standard deviation. Qualitative data were expressed as frequency and percentage. Chi-square test was used in the comparison between two groups with qualitative data and fisher exact test was used instead of the chi-square test when the expected count in any cell found less than 5. For quantitative data, comparison between two groups was done using independent sample t-test. The confidence interval was set to $95 \%$ and the margin of error accepted was set to $5 \%$. So, the pvalue $<0.05$ was considered significant.

\section{RESULTS}

A total of 80 pregnant women were identified with a diagnosis uterine leiomyoma and divided into two groups. Their age ranged from 22 to 37 years. The fibroid size was $<3 \mathrm{~cm}$ in $17(42.5 \%), 16$ (40\%) respectively, $3-6 \mathrm{~cm}$ in 15 $(37.5 \%), 14(35 \%)$ respectively and $>6$ $\mathrm{cm}$ in 8 (20\%), 10 (25\%) respectively. As regard location of fibroid in uterus, it was in the body in $26(65 \%), 24(60 \%)$ respectively, in the fundus in $11(27.5 \%)$, $14(35 \%)$ respectively and in the lower segment in $3(7.5 \%), 2(5 \%)$ respectively. As regard type of fibroid, it was subserous in $25(62.5 \%), 20(50 \%)$ respectively, submucous in $1(2.5 \%), 2(5 \%)$ respectively and intramural in 14(35\%), $18(45 \%)$ respectively. It was single in $28(70 \%), 31$ $(77.5 \%)$ respectively and multiple in 12 (30\%), $10(22.5 \%)$ respectively. There is no significant difference between the two studied groups as regard any of uterine fibroids characteristics (Table 1).

Table (1): Uterine fibroids Characteristics among the two studied groups

\begin{tabular}{|c|c|c|c|c|}
\hline \multicolumn{2}{|c|}{ Fibroid characters } & $\begin{array}{c}\text { Group A } \\
(\mathrm{n}=40)\end{array}$ & $\begin{array}{c}\text { Group B } \\
(\mathrm{n}=40)\end{array}$ & $\mathbf{P}$ \\
\hline \multirow{3}{*}{ Size } & $<3 \mathrm{~cm}$ & $17(42.5 \%)$ & $16(40 \%)$ & \multirow{3}{*}{0.87} \\
\hline & $3-6 \mathrm{~cm}$ & $15(37.5 \%)$ & $14(35 \%)$ & \\
\hline & $>6 \mathrm{~cm}$ & $8(20 \%)$ & $10(25 \%)$ & \\
\hline \multirow{3}{*}{ Location } & Body & $26(65 \%)$ & $24(60 \%)$ & \multirow{3}{*}{0.726} \\
\hline & Fundus & $11(27.5 \%)$ & $14(35 \%)$ & \\
\hline & Lower segment & $3(7.5 \%)$ & $2(5 \%)$ & \\
\hline \multirow{3}{*}{ Type } & Subserous & $25(62.5 \%)$ & $20(50 \%)$ & \multirow{3}{*}{0.494} \\
\hline & Submucous & $1(2.5 \%)$ & $2(5 \%)$ & \\
\hline & Intramural & $14(35 \%)$ & $18(45 \%)$ & \\
\hline \multirow{2}{*}{ Number } & Single & $28(70 \%)$ & $31(77.5 \%)$ & \multirow{2}{*}{0.446} \\
\hline & Multiple & $12(30 \%)$ & $9(22.5 \%)$ & \\
\hline
\end{tabular}


The operative time Mean \pm SD was $68.41 \pm 19.32,49.17 \pm 7.35$ minute respectively and hospital stay Mean \pm SD was $3.8 \pm .921,1.68 \pm .946$ days respectively. Operative time and hospital stay are significantly higher in group A compared to group B (Table 2).

Table (2): Operative time and hospital stay of the two studied groups.

\begin{tabular}{|c|c|c|c|}
\hline Groups & $\begin{array}{c}\text { Group A } \\
(\mathrm{n}=40)\end{array}$ & $\begin{array}{c}\text { Group B } \\
(\mathrm{n}=40)\end{array}$ & $\mathbf{p}$ \\
\hline $\begin{array}{c}\text { Operative time (min) } \\
\text { Mean } \pm \text { SD }\end{array}$ & $68.41 \pm 19.32$ & $49.17 \pm 7.35$ & $<\mathbf{0 . 0 0 1}$ \\
\hline $\begin{array}{c}\text { Hospital stay (days) } \\
\text { Mean } \pm \text { SD }\end{array}$ & $3.8 \pm .921$ & $1.68 \pm .946$ & $<\mathbf{0 . 0 0 1}$ \\
\hline
\end{tabular}

Pre/postoperative hemoglobin were slightly lower in group A compared to group B without statistically significant difference and no significant change in hemoglobin value from preoperative to postoperative. Mean blood loss was slightly higher in group A compared to group B without significant difference. Meanwhile blood transfusion and postoperative fever were more frequent in group A but without significant difference (Table 3).

Table (3): Operative outcome between the two studied groups

\begin{tabular}{|c|c|c|c|}
\hline $\begin{array}{ll}\text { Variable } & \text { Groups } \\
\end{array}$ & $\begin{array}{c}\text { Group A } \\
(\mathrm{n}=40)\end{array}$ & $\begin{array}{c}\text { Group B } \\
(\mathrm{n}=40)\end{array}$ & $\mathbf{p}$ \\
\hline $\begin{array}{c}\text { Preoperative Hb }(\mathrm{g} / \mathrm{dl}) \\
\text { Mean } \pm \mathrm{SD}\end{array}$ & $10.92 \pm 1.96$ & $11.04 \pm 1.67$ & 0.769 \\
\hline $\begin{array}{c}\text { Postoperative Hb }(\mathrm{g} / \mathrm{dl}) \\
\text { Mean } \pm \text { SD }\end{array}$ & $8.97 \pm 1.73$ & $9.52 \pm 1.77$ & 0.1639 \\
\hline $\begin{array}{c}\text { Blood loss }(\mathrm{ml}) \\
\text { Mean } \pm \text { SD }\end{array}$ & $698.2 \pm 43.71$ & $602.3 \pm 49.22$ & $<0.001$ \\
\hline Blood transfusion $\mathrm{n}(\%)$ & $3(7.5 \%)$ & $1(2.5 \%)$ & 0.305 \\
\hline $\begin{array}{c}\text { Postoperative Fever, } \mathrm{n} \\
(\%)\end{array}$ & $2(5 \%)$ & $1(2.5 \%)$ & 0.556 \\
\hline
\end{tabular}

BMI, myomectomy with CS, and fibroid size $3-6 \&>6 \mathrm{~cm}$ were found to significant risk factors for hemorrhage $\mathrm{p}$ value was $0.012,0.026,0.039$ and 0.001 respectively (Table 4). 
Table (4): Multivariate regression analysis to identify the potential risk factors for hemorrhage

\begin{tabular}{|c|c|c|c|c|c|c|}
\hline \multirow{2}{*}{$\begin{array}{l}\text { Misk } \\
\text { factors }\end{array}$} & Beta & $\begin{array}{c}\text { Standard } \\
\text { error }\end{array}$ & \multirow{2}{*}{ OR } & Significant & \multicolumn{2}{|c|}{$\begin{array}{c}\text { 95 \% Confidence } \\
\text { Interval for OR }\end{array}$} \\
\cline { 5 - 7 } & & & & & $\begin{array}{c}\text { Lower } \\
\text { Bound }\end{array}$ & $\begin{array}{c}\text { Upper } \\
\text { Bound }\end{array}$ \\
\hline (Constant) & & 1.266 & 2.222 & 0.096 & 4.881 & 0.437 \\
\hline Age & 0.042 & 0.215 & 0.095 & 0.663 & 0.360 & 0.550 \\
\hline BMI & 0.685 & 0.029 & 0.081 & $\mathbf{0 . 0 1 2}$ & 0.142 & 1.798 \\
\hline $\begin{array}{c}\text { Myomectomy } \\
\text { with CS }\end{array}$ & 0.747 & 0.034 & 0.072 & $\mathbf{0 . 0 2 6}$ & 0.216 & 1.655 \\
\hline Size 3 - 6 cm & 0.878 & 0.011 & 0.066 & $\mathbf{0 . 0 3 9}$ & 0.044 & 0.789 \\
\hline Size > 6 cm & 1.231 & 0.046 & 0.109 & $\mathbf{0 . 0 0 1}$ & 0.280 & 1.838 \\
\hline Multi fibroids & 0.086 & 0.024 & 0.019 & 0.051 & 0.070 & 0.032 \\
\hline Body fibroid & 0.148 & 0.156 & 0.213 & 0.095 & 0.541 & 0.116 \\
\hline Subserous type & 1.070 & 0.382 & 1.537 & 0.103 & 2.338 & 0.737 \\
\hline Submucous type & 0.163 & 0.107 & 0.151 & 0.176 & 0.075 & 0.378 \\
\hline
\end{tabular}

\section{DISCUSSION}

Combining myomectomy with cesarean section has been traditionally discouraged mainly due to the risk of hemorrhage associated with surgery as a result of increased vascularity of the pregnant uterus and uterine atomicity. But if these two procedures can be performed safely and simultaneously, the risk of anaesthetic complications, multiple surgeries, adhesion, cost of the operative procedure, and hospital stay could be reduced. However, recent studies have revealed that myomectomy during cesarean section can be a safe procedure with careful case selection (Shiota et al., 2013).

In our study, there was no significant difference between the two studied groups regarding age, BMI, gravidity and parity numbers.

Our results were in agreement with study of Guler et al. (2020) as they reported that there was no statistically significant difference between the studied groups as regard age, gravidity and parity numbers.

The changes in myoma size during pregnancy are generally individual. Despite controversial results, most reports suggested that myoma growth in pregnancy is much less frequent than previously believed, since some even decrease during pregnancy (Goodman et al., 2015).

The present study showed that there was no significant difference between the two studied groups, however, smoking, and HTN were more frequent in group A while GDM was more frequent in group B. There was no significant difference between the two studied groups as regard any of uterine fibroids characteristics.

Furthermore, Nargis et al. (2019) revealed that there was no significant difference between the two studied groups regarding any of uterine fibroids characteristics.

However, Baby et al. (2015) reported that $15.6 \%$ women had myoma in the fundus, $48.9 \%$ had in the body of the 
uterus and $33.3 \%$ had both in the body and fundus of the uterus. Only $2.2 \%$ had myoma in the cervix. 20\% women had subserous, $55.6 \%$ had intramural, $20 \%$ had both subserous and intramural and $4.4 \%$ had intramural and submucous myomas. In $66.7 \%$ women size of the myoma were less than $5 \mathrm{~cm}$, in $24.4 \%$ varied from $5-10 \mathrm{~cm}$ and in $8.9 \%$ was more than $10 \mathrm{~cm}$ in size.

The current study shows that operative time and hospital stay are significantly higher in group A compared to group B. Our results were in line with study of Nargis et al. (2019) as they observed that duration of operation was significantly prolonged in cesarean myomectomy group which was statistically significant.

Hatırnaz et al. (2018) demonstrated that median myomectomy procedure time and amount of intra-operative bleeding in SM were higher than EM.

In the study in our hands, pre/postoperative hemoglobin were slightly lower in group A compared to group B without statistically significant difference and no significant change in hemoglobin value from preoperative to postoperative. Mean blood loss was slightly higher in group A compared to group B without significant difference. Meanwhile, blood transfusion and postoperative fever were more frequent in group A but without significant difference.

Our results were supported by study of Nargis et al. (2019) as they compared both groups in terms of preoperative and postoperative hemoglobin level and no statistically significant difference was observed. Furthermore, Umezurike et al. (2014) reported that there was no significant difference in EBL (Estimated Blood Loss), incidence of postoperative complications, fetal APGAR score at 5 minutes, as well as duration of hospitalization between both groups. Zhao et al. (2019) observed that there are also no statistical differences in other perioperative outcome variables between the two groups, including fetal distress, neonatal asphyxia, and neonatal birth weight.

In the study in our hands, BMI, myomectomy with CS, and fibroid size 3 $6 \&>6 \mathrm{~cm}$ were found to significant risk factors for hemorrhage. Our results were supported by study of Zhao et al. (2019) as they analyzed the high-risk factors for postpartum hemorrhage $\geq 1,000 \mathrm{ml}$ in pregnant women with uterine fibroids during cesarean section. Their data showed that the presence of a large-sized leiomyoma $\geq 5 \mathrm{~cm}$ and birth weight $\geq 4,000 \mathrm{~g}$ were the important risk factors, while myomectomy during cesarean and the location and type of fibroids have little effects. In line with this study, Dedes et al. (2017) reported that a larger size of fibroid $(\geq 5 \mathrm{~cm})$ and a maternal age more than 40 years are risk factors of increased blood loss in women with uterine fibroids during cesarean.

Senturk et al. (2017) reported that the impact of gravidity, parity, and week of gestation on myomectomy can be explained by their effect on myoma size. We noted that as the number of previous pregnancies, parity and week of gestation increased, the diameter of the fibroids decreased.

\section{CONCLUSION}

Our study indicated that Myomectomy during cesarean section was safe and cost 
effective as it avoids possible Fibroid removal at later age.

\section{RECOMMENDATIONS}

Cesarean myomectomy can be recommended in selected patients. Intraoperative assessment of fibroids is important factor in decision making for caesarean myomectomy.

\section{REFERENCES}

1. Allameh $Z$ and Allameh T. (2019): Successful Myomectomy in the Second Trimester of Pregnancy. Advanced Biomedical Research, 8: 60-9.

2. Baby HA, Begum MR, Ehsan M, Ehsan N, Amin I and Chowdhury AA. (2015): Myomectomy during caesarean section: safety and feasibility of the procedure. Bangladesh Journal of Obstetrics \& Gynaecology, 30(1):10-14.

3. Dedes I, Schäffer L, Zimmermann R, Burkhardt $\mathbf{T}$ and Haslinger $\mathrm{C}$. (2017): Outcome and risk factors of cesarean delivery with and without cesarean myomectomy in women with uterine myomatas. Archives of Gynecology and Obstetrics, 295(1): 27 32.

4. Goodman LR, Valentine $L N$ and Falcone T. (2015): Myoma in pregnancy. In: Tinelli A, Malvasi A, eds. Uterine myoma, myomectomy and minimally invasive treatments. 1st ed. Pbl. Berlin: Springer, Pp. 219-36.

5. Guler AE, Guler ZÇD, Kinci MF and Mungan MT. (2020): Myomectomy During Cesarean Section: Why Do We Abstain From?. The Journal of Obstetrics and Gynecology of India, 1-5.
6. Hatırnaz Ş, Güler O, Başaranoğlu S, Tokgöz C, and Kılıç GS. (2018): Endometrial myomectomy: a novel surgical method during cesarean section. The Journal of Maternal-Fetal \& Neonatal Medicine, 31(4): 433-438.

7. Lee HJ, Norwitz ER and Shaw J. (2010): Contemporary management of fibroids in pregnancy. Rev Obstet Gynecol., 3:20-6.

8. Nair S and Al-Hendy A. (2011): Adipocytes enhance the proliferation of human leiomyoma cells via TNF-a proinflammatory cytokine. Reprod Sci., 18:1186-1192.

9. Nargis N, Karim MI and Loverine S. (2019): Evaluation of safety of caesarean myomectomy: A prospective study. Bangladesh Critical Care Journal, 7(1): 40-43.

10. Senturk MB, Polat M, Doğan O, Pulatoğlu Ç, Yardımcı OD and Karakuş R. (2017): Outcome of cesarean myomectomy: is it a safe procedure? Geburtshilfe und Frauenheilkunde, 77(11): 1200-1206.

11. Shiota M, Kotani Y and Ami K. (2013): Uterus-sparing myomectomy for uterine pyomyoma following cesarean section. Taiwan J Obstet Gynecol., 52: 140-1.

12. Sparic' $\mathbf{R}$, Malvasi A and Tinelli A. (2015): Analysis of clinical, biological and obstetric factors influencing the decision to perform cesarean myomectomy. Ginekol Pol., $86: 40-45$.

13. Tpoçu HO, I'skender CT and Timur H. (2015): Outcomes after cesarean myomectomy versus cesarean 
alone among pregnant women with uterine leiomyomas. Int $\mathbf{J}$ Gynaecol Obstet., 130:244-246.

\section{Umezurike CC, Akwuruoha EM} and Eguzo KN. (2014): A cohort study of maternal and fetal outcomes for myomectomy at caesarean section in Aba, South Eastern Nigeria. International Journal of Reproduction, Contraception, Obstetrics and Gynecology, 3(4): 937-941.

15. Vitale SG, Padula F and Gulino FA. (2015): Management of uterine fibroids in pregnancy: recent trends. Current Opinion in Obstetrics and Gynecology, 27(6): 432-437.

16. Zhang $Y$ and Hua KQ. (2014): Patients' age, myoma size, myoma location, and interval between myomectomy and pregnancy may influence the pregnancy rate and live birth rate after myomectomy. $\mathbf{J}$ Laparoendosc Adv Surg Tech A., 24:95-99.

17. Zhao, R, Wang, $X$, Zou, L, and Zhang, W. (2019): Outcomes of Myomectomy at the Time of Cesarean Section among Pregnant Women with Uterine Fibroids: A Retrospective Cohort Study. Bio Med Research International, 2:321-7.

18. Zimmermann A, Bernuit D, Gerlinger $C$, Schaefers $M$ and Geppert K. (2012): Prevalence, symptoms and management of uterine fibroids. An international internetbased survey of 21,746 women. BMC Womens Health, 2: 12:6. 
تقييم سلامة وفعالية إستنصال الورم الليفي أثناء العملية

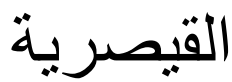

أيمن جميل مرزق رزق محمد, محمد صلاح الدين حسانين, طاهر محمد مصطفي البريري

قسم أمراض النساء و التوليد، كلية الطب، جامعة الأزهر

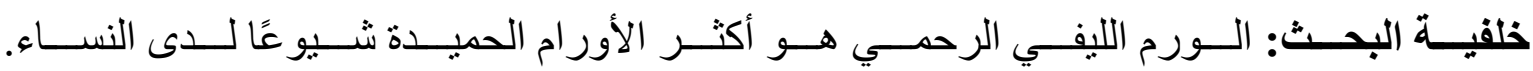

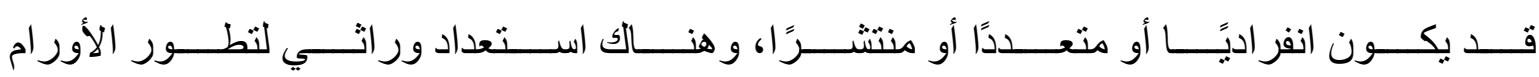
العضلية.

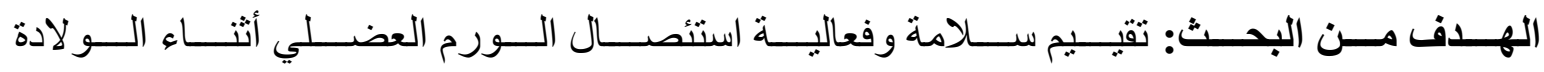

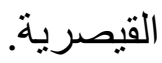

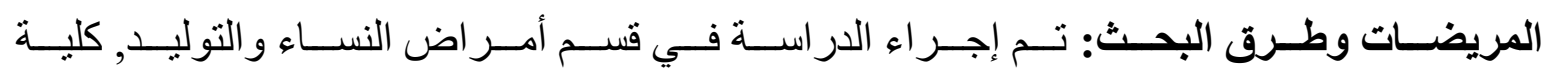

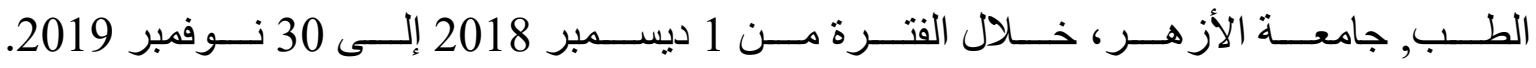

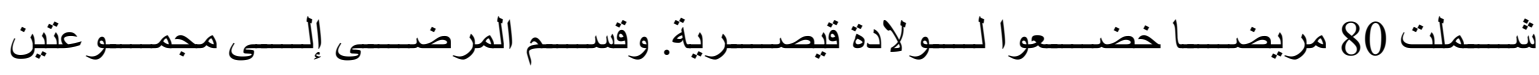

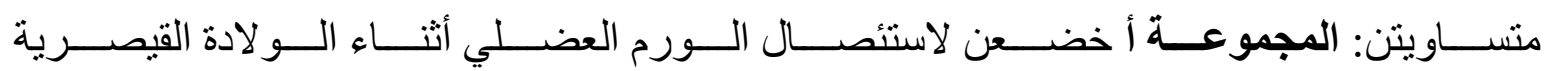
بينما في المجموعة ب خضعن للعملية القيصرية فقط دون أي تدخل آخر.

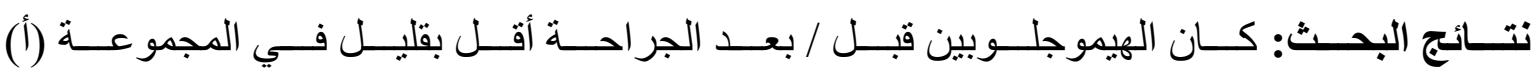

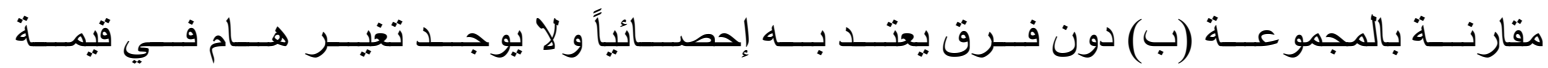

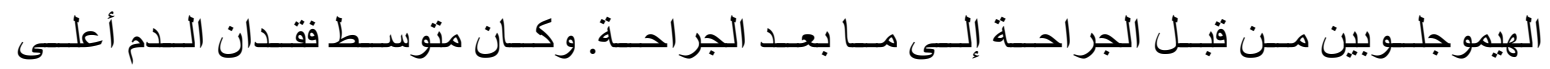

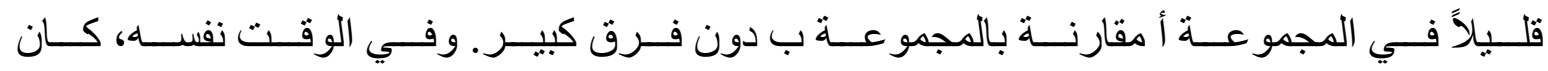

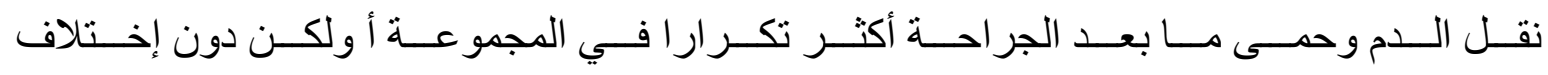

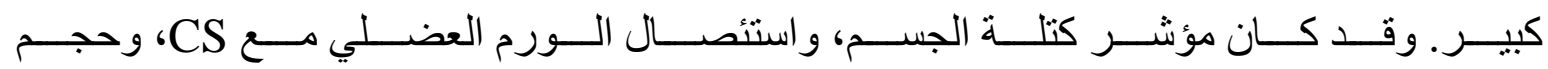

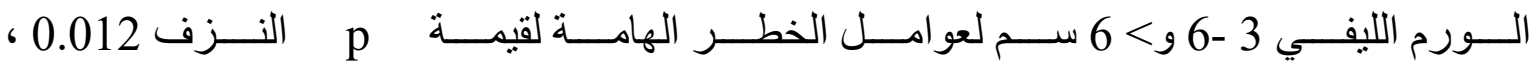
0.026، 0.039 0.039 و 0.001 على التو الي.

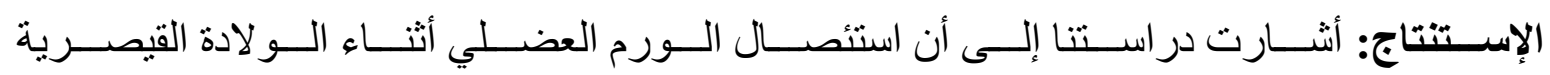
آمن وفعال من حيث التكلفة لأنه يتجنب إز الة الأورام الليفية في سن متأخرة. 